OPEN ACCESS

Edited by:

Oscar Branson,

University of Cambridge,

United Kingdom

Reviewed by:

David Evans,

Goethe University Frankfurt, Germany

Catherine Davis,

Yale University, United States

*Correspondence:

Inge van Dijk

Inge.van.Dijk@nioz.nl

Specialty section:

This article was submitted to Biogeoscience,

a section of the journal

Frontiers in Earth Science

Received: 30 May 2020

Accepted: 10 September 2020

Published: 05 October 2020

Citation:

van Dijk I, de Nooijer LJ, Barras C, Reichart G-J (2020) Mn Incorporation in Large Benthic Foraminifera:

Differences Between Species and the Impact of $\mathrm{pCO}_{2}$.

Front. Earth Sci. 8:567701.

doi: 10.3389/feart.2020.567701

\section{Mn Incorporation in Large Benthic Foraminifera: Differences Between Species and the Impact of $\mathrm{pCO}_{2}$}

\author{
Inge van Dijk ${ }^{1,2 *}$, Lennart J. de Nooijer ${ }^{2}$, Christine Barras ${ }^{1}$ and Gert-Jan Reichart ${ }^{2,3}$ \\ ${ }^{1}$ UMR 6112 LPG-BIAF, Université d'Angers, Université de Nantes, CNRS, Angers, France, ${ }^{2}$ Department of Ocean Systems, \\ NIOZ-Royal Netherlands Institute for Sea Research and Utrecht University, Den Burg, Netherlands, ${ }^{3}$ Faculty of Geosciences, \\ Utrecht University, Utrecht, Netherlands
}

Element concentrations of calcite precipitated by foraminifera reflect chemical and physical properties of seawater and can therefore be used to reconstruct (paleo-)environmental conditions. Foraminiferal carbonate associated manganese incorporation (expressed here as $\mathrm{Mn} / \mathrm{Ca}$ ) is a potential proxy for seawater oxygenation, although the impacts of other environmental parameters need to be quantified before $\mathrm{Mn} / \mathrm{Ca}$ can be robustly applied. Here we report the isolated impact of seawater carbonate chemistry on manganese incorporation in the shells of two large symbiont-bearing benthic foraminiferal species. Moreover, we investigated the role of biomineralization on manganese incorporation by using species with contrasting calcification pathways: the hyaline species Amphistegina gibbosa and the porcelaneous species Sorites marginalis. Furthermore, analyzing shells from a wide range of species grown under identical conditions allowed assessment of species-specific Mn incorporation in other foraminiferal species. Our observations show that species specific differences in biomineralization strategies are the dominant factor determining $\mathrm{Mn}$ content. Shells from porcelaneous species, with relatively high $\mathrm{Mg}$ contents, are generally also enriched in Mn compared to low-Mg/Ca foraminifera. Superimposed on the effect of biomineralization, chemical speciation of elements in seawater as a function of $\mathrm{pCO}_{2}$ also affects their incorporation. Whereas the impact of the carbonate system is limited, the inter-specific differences call for species specific calibrations in order to use Mn uptake as a (paleo-)oxygenation proxy.

Keywords: foraminifera, manganese, carbon chemistry, $\mathrm{pCO}_{2}$, proxy development

\section{INTRODUCTION}

The chemical composition of foraminiferal shells is widely used by paleoceanographers to reconstruct ocean conditions, because past fluctuations in physico-chemical conditions of seawater are recorded in the chemistry of the shell. For example, the $\mathrm{Mg}-\mathrm{Ca}$ ratio $(\mathrm{Mg} / \mathrm{Ca})$ of foraminiferal calcite reflects seawater temperature (Nürnberg et al., 1996) and can hence be applied to fossil foraminifera to reconstruct past bottom water (Lear et al., 2000) and sea surface (Barker et al., 2005) temperatures. The toolbox that foraminiferal calcite provides, is ever expanding by addition of new elements of interest, including e.g., the recently proposed $\mathrm{Sr} / \mathrm{Ca}$ (Keul et al., 2017) and S/Ca (Van Dijk et al., 2017a) as recorders of the seawater carbonate system. In addition, redox sensitive trace metals may serve as proxies to reconstruct (paleo-)oxygenation, a parameter for which accurate reconstruction methods are currently lacking. Manganese $(\mathrm{Mn})$ is a promising candidate for 
such a proxy, since solubility and/or the oxidation state of $\mathrm{Mn}$ is a function of the redox status of the environment (Tribovillard et al., 2006) and pore water carbonate chemistry (Middelburg et al., 1987). Manganese precipitates as a solid phase $\mathrm{Mn}$ oxyhydroxide under oxygenated conditions, but at lower oxygen levels, $\mathrm{Mn}$ oxyhydroxide is reduced and $\mathrm{Mn}^{2+}$ is released into the surrounding seawater. At high carbonate concentrations in the pore water, $\mathrm{Mn}^{2+}$ is removed by precipitation of $\mathrm{Mn}$ carbonate (rhodochrosite). Foraminifera incorporate dissolved $\mathrm{Mn}^{2+}$ (Reichart et al., 2003; Koho et al., 2015; Barras et al., 2018) and therefore the Mn/Ca of their shell is suggested to change with oxygenation conditions (Groeneveld and Filipsson, 2013; Koho et al., 2015; McKay et al., 2015; Ní Fhlaithearta et al., 2018). To further develop this proxy, it is necessary to i) investigate potential other (environmental) parameters influencing $\mathrm{Mn}$ incorporation and ii) obtain species-specific calibrations by culture or field studies, and ultimately iii) understand the incorporation pathways of $\mathrm{Mn}$ during biomineralization.

The influence of the carbonate system (e.g., pH, alkalinity, dissolved inorganic carbon) on foraminiferal $\mathrm{Mn} / \mathrm{Ca}$ has, to our knowledge, not yet been studied. In theory, the carbonate system might have an effect on the $\mathrm{Mn} / \mathrm{Ca}$ of foraminifera, since it is hypothesized that absorption layers might be involved in the incorporation of Mn (Barras et al., 2018) and adsorption on inorganically precipitated calcite depends on $\mathrm{pH}$ (Zachara et al., 1991). At higher $\mathrm{pH}$, adsorption of $\mathrm{Mn}^{2+}$ might increase, which would result in overall higher foraminiferal $\mathrm{Mn} / \mathrm{Ca}$ values. For the small benthic foraminifers Ammonia sp. and Bulimina marginata, thin bands with high $\mathrm{Mn} / \mathrm{Ca}$ are observed at the start of calcite lamellae (Van Dijk et al., 2019b), which could be due to absorption layers that are exposed to the surrounding seawater between chamber formation events, as hypothesized in Barras et al. (2018). These high $\mathrm{Mn} / \mathrm{Ca}$ layers are co-located with high $\mathrm{Mg} / \mathrm{Ca}$ banding and are associated with a carbonateassociated species of Mn (Van Dijk et al., 2019b). Other processes related to seawater carbonate chemistry could also impact element incorporation (Ries et al., 2009). In inorganic calcite, precipitation rate controls incorporation of elements (Mucci, 1987). For Mn, a decreasing precipitation rate increases $\mathrm{Mn}$ partitioning $\left(\mathrm{D}_{\mathrm{Mn}}=\mathrm{Mn} / \mathrm{Ca}_{\mathrm{CALCITE}} / \mathrm{Mn} /\right.$ $\mathrm{Ca}_{\text {SEAwATER }}$ ) and thus favors incorporation of $\mathrm{Mn}$ (Lorens, 1981). This is in contrast to $\mathrm{Mg}$ and Sr partitioning, which increases with calcite growth rate (Mavromatis et al., 2013). Consequently, when calcite precipitation rates in foraminifera are affected by e.g., ocean acidification or inorganic carbon chemistry in general, the effect on $\mathrm{Mn}$ - and Mg-incorporation is expected to be reversed. Unfortunately, so far the response of foraminifera to e.g., ocean acidification seems to be speciesspecific (Keul et al., 2013; Doo et al., 2014) making it difficult to predict overall effect of acidification on element incorporation.

As with other elements, Mn incorporation may well be species-specific, which would require calibration of this proxy for different species (e.g., see summary in Toyofuku et al., 2011). Barras et al. (2018) found that the two benthic species Ammonia tepida and Bulimina marginata, cultured under the same conditions, have a Mn partitioning of 0.08 and 0.6, respectively, an offset of one order of magnitude. Incorporation of $\mathrm{Mn}$ appears to be coupled to that of $\mathrm{Mg}$ (Van Dijk et al., 2019b), similar to what is observed for other elements (Van Dijk et al., 2017b), possibly due to crystal lattice strain (Mucci and Morse, 1983; Evans et al., 2015) or simultaneous uptake (Van Dijk et al., 2019a). Even if the relative sensitivity of $\mathrm{Mn} / \mathrm{Ca}$ to oxygenation is the same for different species, as suggested for certain proxies (e.g., S/Ca; Van Dijk et al., 2017a), the absolute $\mathrm{Mn} / \mathrm{Ca}$ value is still needed for reconstruction of oxygenation. Therefore, $\mathrm{Mn} / \mathrm{Ca}$ values of both hyaline and porcelaneous species have to be known before application of this potential oxygenation proxy.

However, there is no consensus on key processes involved in foraminiferal calcification (review in De Nooijer et al., 2014). Uptake of ions could occur for instance through seawater endocytosis (seawater vacuolization model; Erez, 2003; Bentov et al., 2009) or transmembrane transport (Nehrke et al., 2013; Mewes et al., 2015), and is either precipitated from a closed reservoir (Elderfield et al., 1996; Evans et al., 2018) or by a continuous ion supply where precipitation follows a classical or a non-classical pathway (Jacob et al., 2017). These models do not specify how $\mathrm{Mn}$ is taken up from seawater by the organism and how it is subsequently incorporated into foraminiferal calcite. According to the seawater vacuolization model model, $\mathrm{Mn}$ is transported in a seawater-filled vacuole to the site of calcification (SOC). Whether Mn is actively removed, like is hypothesized for $\mathrm{Mg}$ (Bentov and Erez, 2006), remains to be investigated. In the transmembrane transport model, $\mathrm{Ca}$ is transported through transmembrane channels, which may occasionally transport other cations with a radius close to the $\mathrm{Ca}^{2+}$, like $\mathrm{Zn}^{2+}$ and $\mathrm{Cd}^{2+}$ (Gonçalves et al., 1999). This would also be the case for $\mathrm{Mn}^{2+}$ ions, since the ionic radius of $\mathrm{Mn}^{2+}(0.8 \AA)$ is similar to that of $\mathrm{Ca}^{2+}(1.0 \AA)$. Based on culture evidence, Barras et al. (2018) hypothesize that the incorporated $\mathrm{Mn}$ in the foraminiferal shell might be partly related to an organismal calcification pathway (biological incorporation), as discussed above, in combination with an inorganic pathway (abiological incorporation). This inorganic pathway involves adsorption of $\mathrm{Mn}$ ions on specific sites on the exposed outer surface of the calcite shells (Mucci and Morse, 1983) in between chamber formation events. Clearly, further research is needed to understand $\mathrm{Mn}$ pathways and create a fundamental basis to explain the empirical relation between foraminifera $\mathrm{Mn}$ and the concentration of dissolved oxygen and seawater [Mn].

In this study we address the major issues mentioned above by investigating the effect of seawater carbonate chemistry on shell $\mathrm{Mn} / \mathrm{Ca}$ values. Observations are used to evaluate the proposed possible pathways of $\mathrm{Mn}$ during foraminiferal calcification. We investigated single-chamber $\mathrm{Mn} / \mathrm{Ca}$ values from a controlled culture experiment with two larger benthic species of foraminifera, Amphistegina gibbosa hosting diatom symbionts (Lee et al., 1995), which precipitates a hyaline shell with intermediate $\mathrm{Mg} / \mathrm{Ca}(\sim 2 \% \mathrm{wt} \mathrm{Mg})$ and porcelaneous species Sorites marginalis, which calcifies a shell with high $\mathrm{Mg}$ content (>4\% wt Mg) and host dinoflagellates (Müller-Merz and Lee, 1976). Specimens were cultured in one of four different conditions, with a $\mathrm{pCO}_{2}$ of $350,450,760$, or $1,200 \mathrm{ppm}$, to 
TABLE 1 | Carbon parameters of the culture media per $\mathrm{pCO}_{2}$ set-point.

\begin{tabular}{|c|c|c|c|c|c|c|}
\hline \multirow[t]{2}{*}{ Treatment } & \multirow{2}{*}{$\frac{\text { Set-point }}{\mathrm{pCO}_{2} \text { (ppm) }}$} & \multirow{2}{*}{$\frac{\text { Measured }}{\text { TA }(\mu \mathrm{mol} / \mathrm{kg})}$} & \multicolumn{4}{|c|}{ Calculated CO2SYS } \\
\hline & & & DIC ( $\mu \mathrm{mol} / \mathrm{kg})$ & {$\left[\mathrm{CO}_{3}{ }^{2-}\right](\mu \mathrm{mol} / \mathrm{kg})$} & $\begin{array}{c}\text { pH (total } \\
\text { scale) }\end{array}$ & $\Omega_{\text {CALCITE }}$ \\
\hline$A$ & 350 & $2,302.8 \pm 8.2$ & $2,007.5 \pm 10.7$ & 220.7 & 8.06 & 5.4 \\
\hline$B$ & 450 & $2,305.2 \pm 5.8$ & $2,021.3 \pm 12.5$ & 200.0 & 8.01 & 4.9 \\
\hline $\mathrm{C}$ & 760 & $2,304.4 \pm 0.9$ & $2,100.8 \pm 13.4$ & 153.7 & 7.87 & 3.7 \\
\hline$D$ & 1,200 & $2,300.3 \pm 0.7$ & $2,201.4 \pm 4.1$ & 92.2 & 7.61 & 2.2 \\
\hline
\end{tabular}

Total alkalinity (TA) and dissolved inorganic carbon (DIC) have been measured directly, the other carbon parameters are calculated with CO2SYS. For details see van Dijk et al. (2017).

study the effect of the carbonate system on the incorporation of $\mathrm{Mn}$ in foraminiferal calcite. In addition, we analyzed a wide range of species sampled from an Indo-Pacific coral reef aquarium (Ernst et al., 2011) to study species-specific partitioning in hyaline and porcelaneous larger benthic foraminifera from a controlled environment.

\section{METHODS}

\section{Foraminiferal Samples}

In this study we analyzed specimens of two species of foraminifera, A. gibbosa and $S$. marginalis grown under a range of controlled $p \mathrm{CO}_{2}$, as well as larger benthic foraminifera collected from an Indo-Pacific reef aquarium. The experimental design of the culture experiment under different $p \mathrm{CO}_{2}$ has been described in detail in Van Dijk et al. (2017b). In short, different species of larger benthic foraminifera collected in the Caribbean Sea were incubated under controlled conditions at the Caribbean Netherlands Science Institute (CNSI; St. Eustatius). Foraminifera were cultured in groups in $70 \mathrm{ml}$ Falcon ${ }^{\circledR}$ tissue bottles in four batches of seawater with added Calcein $(5 \mathrm{mg} / \mathrm{l})$, which were in equilibrium with four different $p \mathrm{CO}_{2}(350,450$, 760 , and 1,200 ppm named, respectively, treatment $\mathrm{A}, \mathrm{B}, \mathrm{C}$, and D) by a $p \mathrm{CO}_{2}$-control system developed in-house (described in detail in Webb et al., 2017). Culture media was replaced every 4 days. At the start and termination of the experiment, $125 \mathrm{ml}$ samples from the stock seawater solutions (one for each experimental treatment) were collected to analyze the concentration of dissolved inorganic carbon and total alkalinity on a Versatile INstrument for the Determination of Titration Alkalinity at the CNSI. Physico-chemical parameters of the culture conditions can be found in Table 1. Foraminifera were cultured at $25 \pm 0.2^{\circ} \mathrm{C}$ for 21 days, during which they build on average 2.4 and 5.0 chambers for A. gibbosa and S. marginalis, respectively. After termination of the experiment, specimens were rinsed three times with de-ionized water and dried at $40^{\circ} \mathrm{C}$. Foraminiferal samples were transported in slides to the Royal Netherlands Institute for Sea Research (NIOZ) to investigate the $\mathrm{Mn} / \mathrm{Ca}$ of the shell and growth parameters. To assess the number of chambers added during the experiment, fluorescent calceinstained chambers were counted using a ZEISS Axioplan 2 fluorescence microscope equipped with appropriate excitation and emission optics. Pictures were taken using a ZEISS Axiocam MRc 5 camera.

At Burgers' Zoo in Arnhem, Netherlands, coral debris, rich in foraminifera (Ernst et al., 2011) were collected from the Indo-
Pacific coral reef aquarium, one of the largest coral reef aquaria in the world. From these coral debris, hyaline (Amphistegina lessonii and Heterostegina depressa) and porcelaneous (Sorites orbiculus, Spiroculina angulata, Spiroculina communis, Quinqueloculina pseudoreticulata, Quinqueloculina sp.) species of foraminifera were isolated to analyze the shell chemistry. Foraminifera from both the experiment and the aquarium were cleaned following an adapted version of the Barker protocol (Barker et al., 2003), described in Van Dijk et al. (2017a, 2017b). In short, foraminifera were cleaned using an oxidizing step in which organics were removed with a $1 \% \mathrm{H}_{2} \mathrm{O}_{2}$ solution (buffered with $0.1 \mathrm{M} \mathrm{NH}_{4} \mathrm{OH}$ ), and consequently, after gentle ultrasonication, rinsed with ultrapure water and dried in a laminar flow cabinet.

\section{Foraminiferal Carbonate Analyses Laser Ablation-Inductively Coupled Plasma Mass Spectrometry}

Elemental composition of individual fluorescent chambers of cultured specimens was analyzed by laser ablation-inductively coupled plasma mass spectrometry (ICP-MS) (Reichart et al., 2003; Van Dijk et al., 2017b). In short, the laser system comprising of an ArF Excimer laser (Existar) with deep UV $193 \mathrm{~nm}$ wavelength and <4 ns pulse duration (NWR193UC, New Wave Research) was equipped with a Two Volume 2 cell (New Wave Research), characterized by a wash-out time of $1.8 \mathrm{~s}$ ( $1 \%$ level). Single chambers were ablated in a helium environment using a circular laser spot with a diameter of $80 \mu \mathrm{m}$ (S. marginalis) and $60 \mu \mathrm{m}$ (A. gibbosa). Foraminifera were previously analyzed (Van Dijk et al., 2017b), but at that time Mn could not be included as an analyte due to interferences with ArN due to the addition of $\mathrm{N}_{2}$ to obtain better counting statistics for e.g., $\mathrm{Na}$. Whenever possible, we re-ablated all calcein-stained chambers one to three times. All foraminiferal samples were ablated with an energy density of $1.0 \pm 0.1 \mathrm{~J} / \mathrm{cm}^{2}$ and a repetition rate of $6 \mathrm{~Hz}$. The resulting aerosol was transported with a helium/argon flow to the quadrupole ICP-MS (iCAP Q, Thermo Scientific). Other monitored masses included ${ }^{7} \mathrm{Li},{ }^{23} \mathrm{Na},{ }^{24} \mathrm{Mg},{ }^{25} \mathrm{Mg},{ }^{27} \mathrm{Al},{ }^{43} \mathrm{Ca}$, ${ }^{44} \mathrm{Ca},{ }^{55} \mathrm{Mn},{ }^{88} \mathrm{Sr}$, and ${ }^{137} \mathrm{Ba}$.

At the start of each series we analyzed several carbonate standards, including JCt-1 (coral carbonate) and two in-house standards, namely NFHS (NIOZ Foraminifera House Standard; Mezger et al., 2016) as well as an Iceland spar NCHS (NIOZ Calcite House Standard). At the end of each series we analyzed SRM NIST612 and NIST610 glass standard in triplicate (using an energy density of $5.0 \pm 0.1 \mathrm{~J} / \mathrm{cm}^{2}$ ). We further analyzed JCp-1 (coral, Porites sp.; Okai et al., 2002) and MACS-3 (synthetic 
TABLE 2 | Summary of the number of specimens and ablations (in brackets) per species per condition (Treatment A, B, C and D) analyzed by LA-Q-ICP-MS.

\begin{tabular}{lcccc} 
Treatment & A & B & C & D \\
\hline$p \mathrm{CO}_{2}(\mathrm{ppm})$ & 350 & 450 & 760 & 1,200 \\
A. gibbosa & $11(25)$ & $28(74)$ & $21(51)$ & $15(43)$ \\
S. marginalis & $10(33)$ & $7(21)$ & $14(42)$ & $18(54)$ \\
\hline
\end{tabular}

calcium carbonate) at the start of each series, and to monitor drift after every ten samples. All element to calcium ratios were calculated with an adapted version of the MATLAB based program Signal Integration for Laboratory Laser Systems (Guillong et al., 2008). Signal Integration for Laboratory Laser Systems was modified by NIOZ to evaluate LA-ICP-MS measurements on foraminifera, allowing import of Thermo Qtegra software sample list, laser data reduction and laser LOG files (as described in Mezger et al., 2016; Van Dijk et al., 2017b). Some major adaptions include improved automated integration and evaluation of (calibration and monitor) standards, quality control report of the monitor standards and export in element to calcium ratios ( $\mathrm{mmol} /$ mol). Integration profiles were manually selected for evaluation, by e.g., monitoring decrease in Ca counts and the $\mathrm{Al}$ signal, which can be used as a sign of potential contamination or diagenesis of the outer or inner layer of calcite. Calibration was performed against the MACS- 3 carbonate standard, with ${ }^{43} \mathrm{Ca}$ as an internal standard and the multiple measurements of MACS-3 were used to apply a linear drift correction. Relative analytical precision, expressed as the relative standard deviation (RSD) of all MACS-3 analyses, is $3 \%$ for ${ }^{7} \mathrm{Li} / \mathrm{Ca}, 3 \%{ }^{23} \mathrm{Na} / \mathrm{Ca}, 3 \%$ for ${ }^{24} \mathrm{Mg} / \mathrm{Ca}, 3 \%$ for ${ }^{25} \mathrm{Mg} / \mathrm{Ca}, 2 \%$ for ${ }^{55} \mathrm{Mn} / \mathrm{Ca}, 3 \%$ for ${ }^{88} \mathrm{Sr} / \mathrm{Ca}$, and $3 \%$ for ${ }^{137} \mathrm{Ba} / \mathrm{Ca}$. Accuracy, based on values for JCp-1 standardized to MACS-3, was 95 and $93 \%$ for $\mathrm{Mg} / \mathrm{Ca}$ and $\mathrm{Mn} / \mathrm{Ca}$, respectively.

In total, 193 and 150 analyses were performed on A. gibbosa and $S$. marginalis, respectively (see Supplementary Material Data Sheet). For details on the amount of specimens and analysis per species, see Table 2 . We removed outliers, 13 in total, from the database based on $1.5 \times$ interquartile range of $\mathrm{Mn}$ / $\mathrm{Ca}$. Furthermore, we calculated the average $\mathrm{Mn} / \mathrm{Ca}$ and $\mathrm{Mg} / \mathrm{Ca}$ per species per treatment and partition coefficient between seawater and foraminiferal calcite, $\mathrm{D}$, which is expressed as $\mathrm{D}_{\mathrm{E}}$ $=\left(\mathrm{E} / \mathrm{Ca}_{\mathrm{CALCITE}}\right) /\left(\mathrm{E} / \mathrm{Ca}_{\mathrm{SW}}\right)$, in which $\mathrm{E}$ is the element of interest. Since these foraminifera were previously analyzed, we also compare our new data with the $\mathrm{Mg} / \mathrm{Ca}$ data of a previous study (Van Dijk et al., 2017b).

\section{Sector Field-Inductively Coupled Plasma Mass Spectrometry}

Foraminifera from Burgers' Zoo were grouped per species (A. lessonii, Heterostegina depressa, Sorites orbiculus, Spiroculina angulate, Spiroloculina communis, Quinqueloculina pseudoreticulata, and Quinqueloculina sp.) and dissolved in $0.5 \mathrm{ml} 0.1 \mathrm{M} \mathrm{HNO}_{3}$. A $5 \mathrm{~s}$ pre-scan for ${ }^{43} \mathrm{Ca}$ was performed on an Element 2 sector field double focusing mass spectrometer (SFICP-MS) to determine the [Ca] in the dissolved foraminiferal calcite solutions. According to these results, samples were diluted to $100 \mathrm{ppm} \mathrm{Ca}$. Elemental composition of the foraminifera was measured for a wide range of isotopes, including ${ }^{24} \mathrm{Mg},{ }^{55} \mathrm{Mn}$, ${ }^{43} \mathrm{Ca}$ at medium resolution with a $300 \mathrm{ml} / \mathrm{min}$ flowrate using a peristaltic pump. Samples were measured against six ratio calibration standards with similar matrix. In addition to the foraminiferal samples, we measured several standards to monitor drift and the quality of the analyses, including NFHS (NIOZ Foraminifera House Standard; for details see Mezger et al., 2016), JCt-1 (Giant Clam, Tridacna gigas) and JCp-1 (coral, Porites sp.; Okai et al., 2002). One of the ratio calibration standards was measured after every fifth sample to monitor drift. Accuracy of Mg/Ca is 105 and $101 \%$ for JCt- 1 and JCp-1, respectively, with an external precision of $0.4 \%$ for both standards. For Mn/Ca, only MACS-3 has a certified value, and accuracy of our measurements is $101 \%$ when using this standard.

\section{Seawater Measurements}

The sampling strategy and general seawater composition $(\mathrm{Ca}$, $\mathrm{Mg}, \mathrm{Na}, \mathrm{Sr}$ and $\mathrm{Ba}$ ) of the media used in the $p \mathrm{CO}_{2}$ controlled experiment has been described in Van Dijk et al. (2017b). In short, at the start and end of the experiment and during replacement of the culture media every four days, subsamples were collected and acidified with three times Quartz distilled $\mathrm{HCl}$ to $\mathrm{pH} \sim 1.8$. Additionally, seawater from the aquarium in Burgers' Zoo was sampled during collection of coral debris at two different occasions. In total, we collected three seawater samples (total $n=6$ ) in $50 \mathrm{ml}$ Falcon tubes, which were returned to the laboratory, acidified and stored at $7^{\circ} \mathrm{C}$ upon analysis. The seawater composition of the experimental samples as well as the Burgers' Zoo seawater was analyzed on an Element-2 SF-ICPMS run in medium resolution mode. International Association for the Physical Sciences of the Ocean Standard Seawater was used as a drift monitor. Analytical precision (RSD) was 3\% for $\mathrm{Ca}, 4 \%$ for $\mathrm{Mg}, 1 \% \mathrm{Na}, 1 \%$ for $\mathrm{Sr}$ and $5 \% \mathrm{Ba}$. For the samples of the culture experiment, we obtained average values of $5.25 \pm$ $0.06 \mathrm{~mol} / \mathrm{mol}$ for $\mathrm{Mg} / \mathrm{Ca}, 44.6 \pm 0.6 \mathrm{~mol} / \mathrm{mol}$ for $\mathrm{Na} / \mathrm{Ca}$, $8.63 \pm 0.05 \mathrm{mmol} / \mathrm{mol}$ for $\mathrm{Sr} / \mathrm{Ca}$, and $9.04 \pm 0.47 \mu \mathrm{mol} / \mathrm{mol}$ for $\mathrm{Ba} / \mathrm{Ca}$. For Burgers' Zoo seawater, $\mathrm{Mg} / \mathrm{Ca}$ was $6.1 \pm$ $0.9 \mathrm{~mol} / \mathrm{mol}$

Due to the low concentration, $[\mathrm{Mn}]$ of subsamples from the culture experiment and tropical aquarium had to be analyzed using a commercially available pre-concentration system, SeaFAST S2. With the SeaFAST system elements with low concentrations are pre-concentrated to values above detection limit of the SF-ICP-MS. Accordingly, we measured Cd, Pb, U, B, $\mathrm{Ti}, \mathrm{Mn}, \mathrm{Fe}, \mathrm{Co}, \mathrm{Ni}, \mathrm{Cu}$, and $\mathrm{Zn}$. In short, $10 \mathrm{ml}$ of sample was mixed with an ammonium acetate buffer to $\mathrm{pH} 6.2$ and loaded on a column containing NOBIAS chelating agent. After rinsing the column with a diluted ammonium acetate buffer the metals were eluted in $750 \mu \mathrm{L}$ of quartz distilled $1.5 \mathrm{M} \mathrm{HNO}_{3}$ before being quantified on the SF-ICP-MS. Analytical precision (RSD) was $4 \%$ for $\mathrm{Mn}$ and we obtained an average seawater $\mathrm{Mn} / \mathrm{Ca}$ value of $5.4 \pm$ $0.3 \mu \mathrm{mol} / \mathrm{mol}$ for the culture experiment, and of $14.8 \pm 0.2 \mu \mathrm{mol} /$ mol for the Burgers' Zoo samples. 

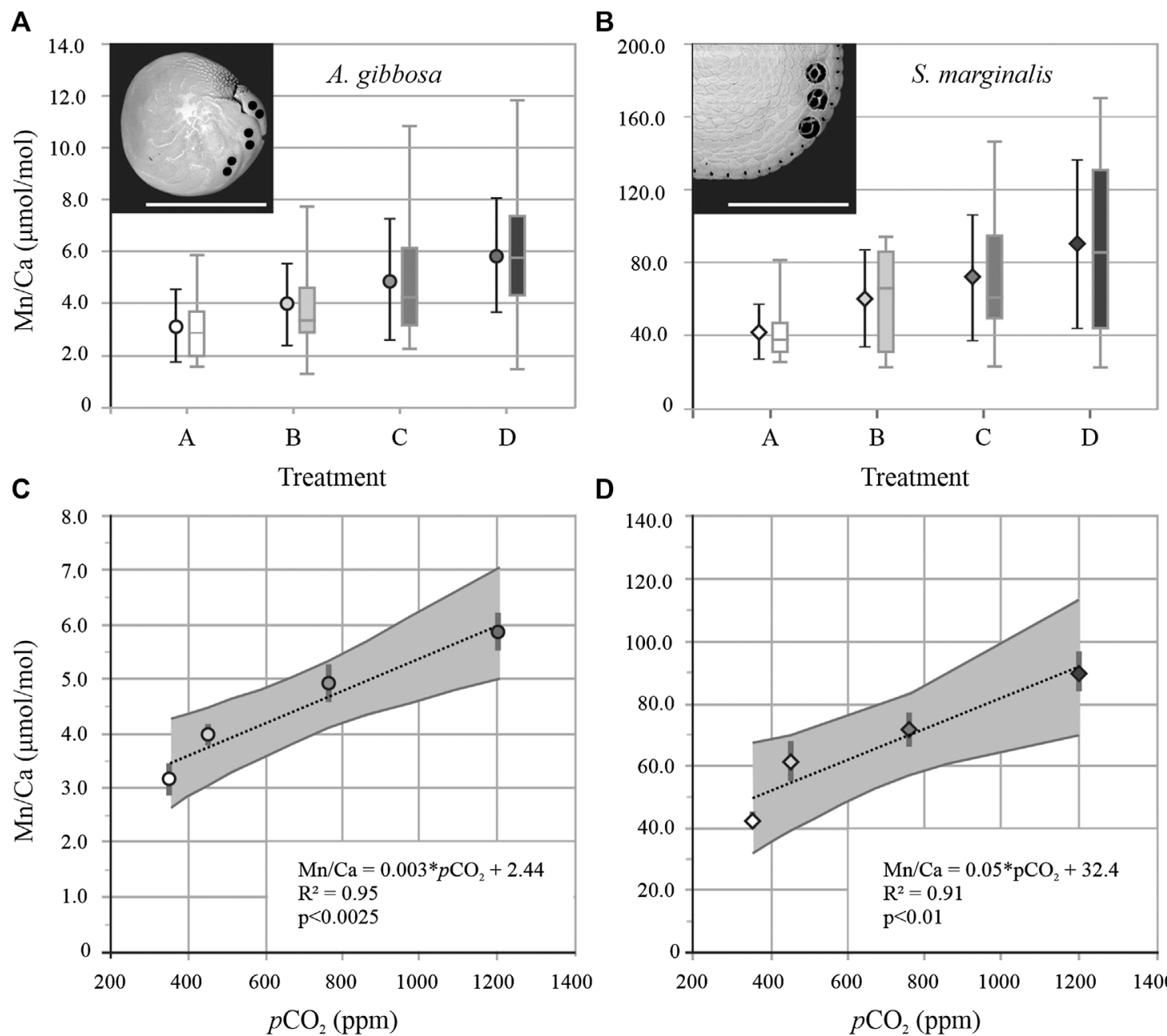

D

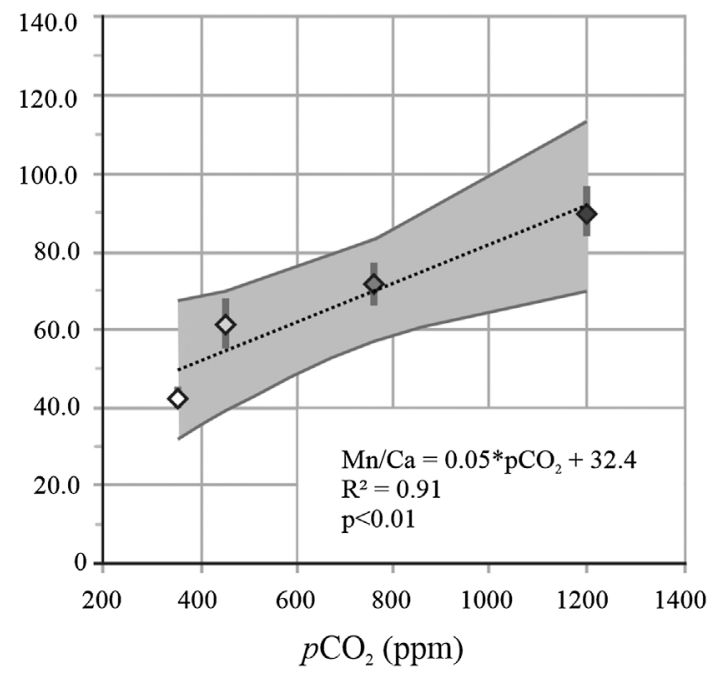

FIGURE 1 | Average foraminiferal Mn/Ca with standard deviation and boxplot of all datapoints per treatment A, B, C, and D for A. gibbosa (A; circles) and Sorites marginalis (B; diamonds). Insets show SEM images of both species with laser ablation spots visible. Scale bar = 500 $\mu \mathrm{m}$. Average Mn/Ca \pm standard error (gray bar) vs. $p \mathrm{CO}_{2}$, with regression line and 95\% confidence interval (gray area) for $A$. gibbosa $\left(\mathbf{C} ; \mathrm{Mn} / \mathrm{Ca}=0.003 \times p \mathrm{CO}_{2}+2.44\right.$ with $R^{2}=0.95$ and $\left.p<0.0025\right)$ and $\mathrm{S}$. marginalis $(\mathbf{D}$ $\mathrm{Mn} / \mathrm{Ca}=0.05 \times \mathrm{pCO}_{2}+32.4$ with $R^{2}=0.91$ and $\left.p<0.01\right)$

\section{RESULTS}

\section{Foraminiferal $\mathrm{Mn} / \mathrm{Ca}$ and $\mathrm{Mg} / \mathrm{Ca}$ vs. $\mathrm{pCO}_{2}$ From Controlled Experiments}

For the hyaline species A. gibbosa, $\mathrm{Mn} / \mathrm{Ca}$ is $4.4 \pm 2.1 \mu \mathrm{mol} / \mathrm{mol}$ for all measurements on average. When $\mathrm{COO}_{2}$ increases from 350 to $1,200 \mathrm{ppm}$, average $\mathrm{Mn} / \mathrm{Ca}$ increase significantly ( $p<$ $\left.0.0025 ; R^{2}=0.95\right)$ with $p \mathrm{CO}_{2}$ (Figure 1C). From lowest to highest $p \mathrm{CO}_{2}$ condition, $\mathrm{Mn} / \mathrm{Ca}$ increases from 3.2 to $5.9 \mu \mathrm{mol} /$ mol (Figure 1A), an overall increase of factor 1.9, or $22 \%$ per $100 \mathrm{ppm} \mathrm{CO}_{2}$. For the correlation between $\left[\mathrm{CO}_{3}{ }^{2-}\right]$ and $\mathrm{pH}$ with $\mathrm{Mn} / \mathrm{Ca}$, see Supplementary Figure S1. Mn/Ca of the porcelaneous species $S$. marginalis are $\sim 11$ times higher than the hyaline species A. gibbosa. For this species, $\mathrm{Mn} / \mathrm{Ca}$ increases significantly with $p \mathrm{CO}_{2}$ as well $\left(p<0.01 ; R^{2}=\right.$ 0.91 ; Figure 1D) by a factor of 2.1 , or $25 \%$ per $100 \mathrm{ppm}$
$\mathrm{CO}_{2}$, from 42.7 to $90.3 \mu \mathrm{mol} / \mathrm{mol}$. For both species, standard deviation (SD) per treatment increases with increasing $p \mathrm{CO}_{2}$, and hence increasing $\mathrm{Mn} / \mathrm{Ca}$. For A. lessonii, the relative SD (RSD) is on average $40 \%$ for the different conditions, while for S. marginalis, the RSD increases from 35 to $51 \%$ with increasing $p \mathrm{CO}_{2}$.

Individual measurements of $\mathrm{Mn} / \mathrm{Ca}$ and $\mathrm{Mg} / \mathrm{Ca}$ for both species are shown in Figure 2. Average $\mathrm{Mg} / \mathrm{Ca}$ is $27.4 \pm 5.3$ and $141.9 \pm 5.3 \mathrm{mmol} / \mathrm{mol}$ for $A$. gibbosa and S. marginalis, respectively (Table 3 ), which fits very well with earlier measurements on the same specimens, where the average $\mathrm{Mg}$ / Ca values obtained were 27.7 and $145.8 \mathrm{mmol} / \mathrm{mol}$, respectively (Van Dijk et al., 2017b), illustrating the good reproducibility of the LA-ICP-MS analyses. Partitioning of $\mathrm{Mg}$ and $\mathrm{Mn}$ is, on average respectively 4.7 and 13.5 times higher in S. marginalis compared to A. gibbosa. 

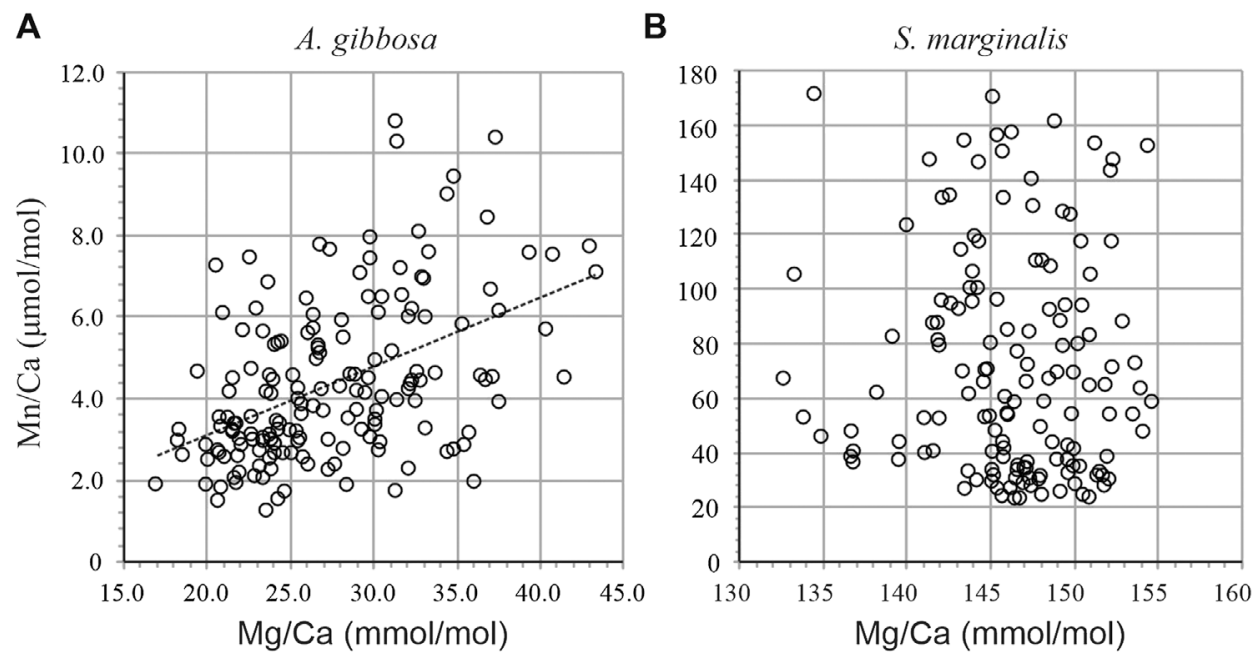

Figure 2 | Mn/Ca vs. Mg/Ca of individual laser ablation measurements for A. gibbosa (A) and S. marginalis (B). For A. gibbosa, Mn/Ca increases with Mg/Ca following $\mathrm{Mn} / \mathrm{Ca}=0.17 \times \mathrm{Mg} / \mathrm{Ca}-0.23$.

TABLE $3 \mid \mathrm{Mn} / \mathrm{Ca}$ and $\mathrm{Mg} / \mathrm{Ca}$ [ \pm standard deviation (SD)] and element partitioning with propagating SD of hyaline species Amphistegina gibbosa and porcelaneous species Sorites marginalis cultured at different $\mathrm{pCO}_{2}$

\begin{tabular}{|c|c|c|c|c|c|}
\hline Species & $\mathrm{pCO}_{2}$ (ppm) & $\mathrm{Mn} / \mathrm{Ca}(\mu \mathrm{mol} / \mathrm{mol} \pm \mathrm{SD})$ & $\mathrm{D}_{\mathrm{Mn}}$ & $\mathrm{Mg} / \mathrm{Ca}(\mathrm{mmol} / \mathrm{mol} \pm \mathrm{SD})$ & $D_{\mathrm{Mg}} \times 1,000$ \\
\hline \multirow{2}{*}{ Amphistegina gibbosa } & 450 & $4.0 \pm 1.6$ & $0.73 \pm 0.29$ & $25.3 \pm 5.4$ & $4.8 \pm 1.1$ \\
\hline & 760 & $4.8 \pm 2.2$ & $0.89 \pm 0.40$ & $30.5 \pm 4.5$ & $5.7 \pm 0.8$ \\
\hline \multirow[t]{3}{*}{ Sorites marginalis } & 350 & $42.7 \pm 14.9$ & $7.9 \pm 2.7$ & $142.6 \pm 5.3$ & $27.2 \pm 1.0$ \\
\hline & 450 & $61.7 \pm 27.4$ & $11.3 \pm 5.0$ & $148.1 \pm 3.3$ & $28.2 \pm 0.6$ \\
\hline & 760 & $71.9 \pm 35.0$ & $13.2 \pm 6.4$ & $147.9 \pm 3.4$ & $28.2 \pm 0.6$ \\
\hline
\end{tabular}

\section{Foraminiferal Growth as a Function of $\mathrm{pCO}_{2}$ From Controlled Experiments}

On average for all conditions, $\sim 80 \%$ of the specimens of $S$. marginalis (for example, see Figure 3B) added new chambers during the experiment, vs. $\sim 90 \%$ of $A$. gibbosa individuals (for example, see Figure 3C). There is no significant trend of chamber addition rate (number of chambers added per day) with $p \mathrm{CO}_{2}$ for both species studied (Figure 3A). On average, specimens of $S$. marginalis added more than two times as many chambers during the culture period, $0.28 \pm 0.12$ chamber per day vs. $0.12 \pm 0.05$ for specimens of $A$. gibbosa.

\section{Mn and Mg Partitioning of Foraminifera From the Indo-Pacific Aquarium}

On average partitioning of $\mathrm{Mn}\left(\mathrm{D}_{\mathrm{Mn}}\right)$ and $\mathrm{Mg}\left(\mathrm{D}_{\mathrm{Mg}} \times 10^{3}\right)$ are, respectively: $0.8 \pm 0.4$ and $5.5 \pm 0.1$ for A. lessonii, $1.9 \pm 0.8$ and $26.7 \pm 0.3$ for $H$. depressa, which are both hyaline species; and $16.2 \pm 3.2$ and $26.7 \pm 0.4$ for $S$. orbiculus, $11.8 \pm 1.6$ and $25.3 \pm 0.4$ for S. angulata, $18.6 \pm 1.9$ and $22.5 \pm 0.4$ for S. communis, $23.0 \pm$ 1.8 and $25.9 \pm 0.4$ for Q. pseudoreticulata and $20.4 \pm 2.7$ and
$23.5 \pm 0.4$ for Quinqueloculina sp., which are five porcelaneous species (see Table 4). The $D_{M n}$ and $D_{M g}$ values are plotted together to visualize possible trends between the two groups of foraminifera (Figure 4). In general, porcelaneous species incorporate more $\mathrm{Mn}$ than hyaline species and the species investigated have similar $\mathrm{Mg}$ content $\left(D_{\mathrm{Mg}} \times 10^{3}\right.$ of 22.5-26.7). In contrast, hyaline species comprise a wider range in $D_{\mathrm{Mg}}$ compared to the porcelaneous species.

\section{DISCUSSION}

\section{Mn Incorporation as a Function of $p \mathrm{CO}_{2}$}

For both species studied here, the hyaline A. gibbosa and the porcelaneous $S$. marginalis, we observe that shell Mn/Ca increases with increasing $\mathrm{pCO}_{2}$ (and hence decreasing sea water $\mathrm{pH}$, $\left[\mathrm{CO}_{3}{ }^{2-}\right]$ or $\Omega$ ). A similar trend was observed for the same species for $\mathrm{Zn}$ and $\mathrm{Ba}$, but was not found case for elements such as Mg, Na and Sr (Van Dijk et al., 2017b). We do not suggest that $\mathrm{Mn} / \mathrm{Ca}$ values can be used as recorders of the carbonate system, since $\mathrm{Mn} / \mathrm{Ca}$ in foraminiferal shells is hypothesized 

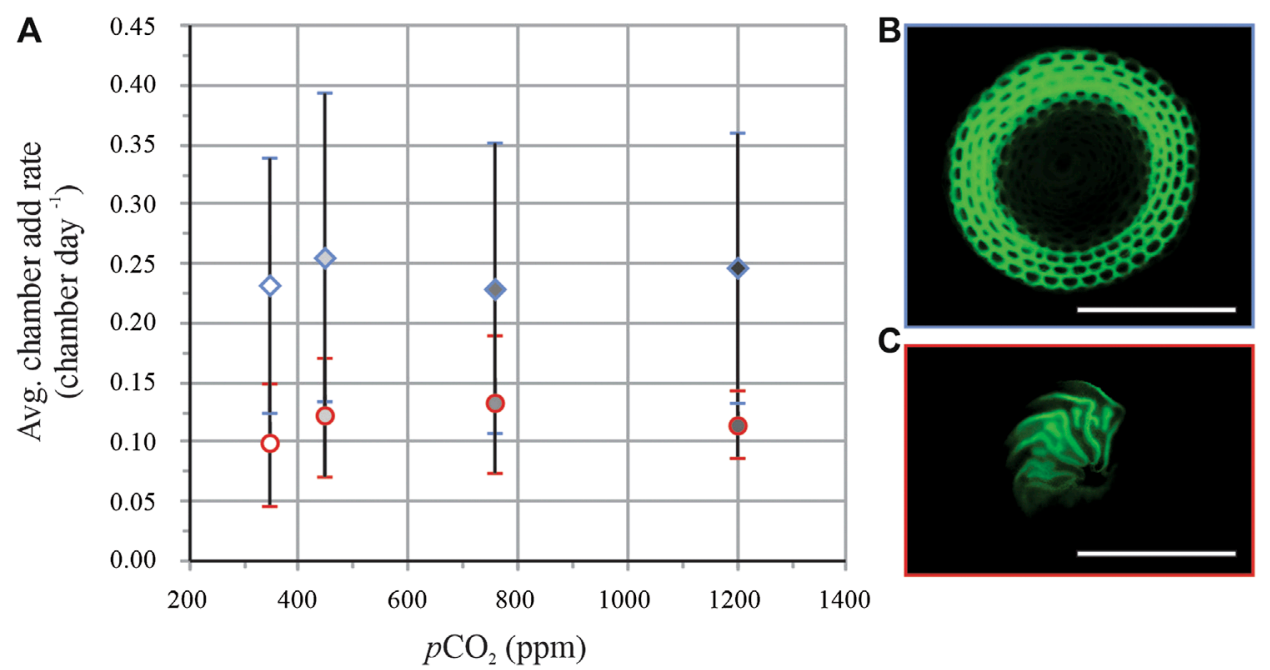

FIGURE 3 |Average chamber addition rates (A) per day $( \pm S D$ ) of S. marginalis (blue diamonds) in blue and $A$. gibbosa (red circles). Right panels show pictures of S. marginalis (B) and A. gibbosa (C).

influenced by seawater [Mn] (Barras et al., 2018), but this could hamper the precision of this proxy (cf. Chapter 4.3). Still, comparing sensitivity of $\mathrm{Mn}$ incorporation to $\mathrm{pCO}_{2}$ to that of other elements provides information on the underlying mechanisms involved in organismal trace element uptake. Even though the slope of the $\mathrm{Mn} / \mathrm{Ca}-\mathrm{pCO}_{2}$ calibrations differs between species ( 0.003 for $A$. gibbosa and 0.05 for $S$. marginalis), the incorporation of $\mathrm{Mn}$ as a function of $p \mathrm{CO}_{2}$ is, in terms of relative sensitivity, similar for A. gibbosa (22\% increase in $\mathrm{Mn} / \mathrm{Ca}$ per $100 \mathrm{ppm} \mathrm{CO}_{2}$ ) and S. marginalis (25\% increase in $\mathrm{Mn} / \mathrm{Ca}$ per $100 \mathrm{ppm}$ increase in $\mathrm{CO}_{2}$ ). This is surprising since these species are known to have contrasting calcification strategies (e.g., Bé et al., 1979; De Nooijer et al., 2009a; Hemleben et al., 1986). This could imply that $\mathrm{Mn}$ incorporation as a function of $p \mathrm{CO}_{2}$ is governed by identical processes in calcification. This might relate to the (active) uptake of trace elements or the subsequent precipitation of carbonate. The first factor inherently includes e.g., symbiont and enzyme activity, speciation of Mn in seawater and $\mathrm{pH}$-dependent absorption of $\mathrm{Mn}$ to calcite. The second factor, actual carbonate precipitation, includes both abiotic

TABLE 4 | Mn and Mg partitioning with propagating standard deviation for species collected from Burgers' Zoo aquarium.

\begin{tabular}{lcc} 
Species & $\mathbf{D}_{\mathbf{M n}}$ & $\mathbf{D}_{\mathbf{M g}} \times \mathbf{1 0}^{\mathbf{3}}$ \\
\hline $\begin{array}{l}\text { Hyaline species } \\
\quad \text { Amphistegina lessonii }\end{array}$ & \\
$\quad$ Heterostegina depressa & $0.8 \pm 0.4$ & $5.5 \pm 0.1$ \\
Porcelaneous species & $1.9 \pm 0.8$ & $26.7 \pm 0.3$ \\
$\quad$ Sorites orbitolis & & \\
$\quad$ Spiroculina angulata & $16.2 \pm 3.2$ & $26.7 \pm 0.4$ \\
$\quad$ Spiroculina communis & $11.8 \pm 1.6$ & $25.3 \pm 0.4$ \\
$\quad$ Quinqueloculina pseudoreticulata & $18.6 \pm 1.9$ & $22.5 \pm 0.4$ \\
Quinqueloculina sp. & $23.0 \pm 1.8$ & $25.9 \pm 0.4$ \\
& $20.4 \pm 2.7$ & $23.5 \pm 0.4$
\end{tabular}

factors such as precipitation rate and also potentially biological controls during this phase.

\section{Impact of $p \mathrm{CO}_{2}$ on Biological Processes}

Growth of marine organisms is, in general, negatively impacted by current changes in oceanic conditions, global warming and ocean acidification (e.g., Orr et al., 2005; Kroeker et al., 2013). For inorganic precipitation experiments, crystal growth rate has a negative effect on incorporation of $\mathrm{Mn}$, resulting in lower $\mathrm{Mn} / \mathrm{Ca}$ values at higher precipitation rates (Lorens, 1981). Therefore, an increase in $\mathrm{Mn}$ incorporation in foraminiferal calcite with $p \mathrm{CO}_{2}$ might be explained by a decrease in the precipitation rate of the foraminiferal shell at higher $p \mathrm{CO}_{2}$, assuming that results from

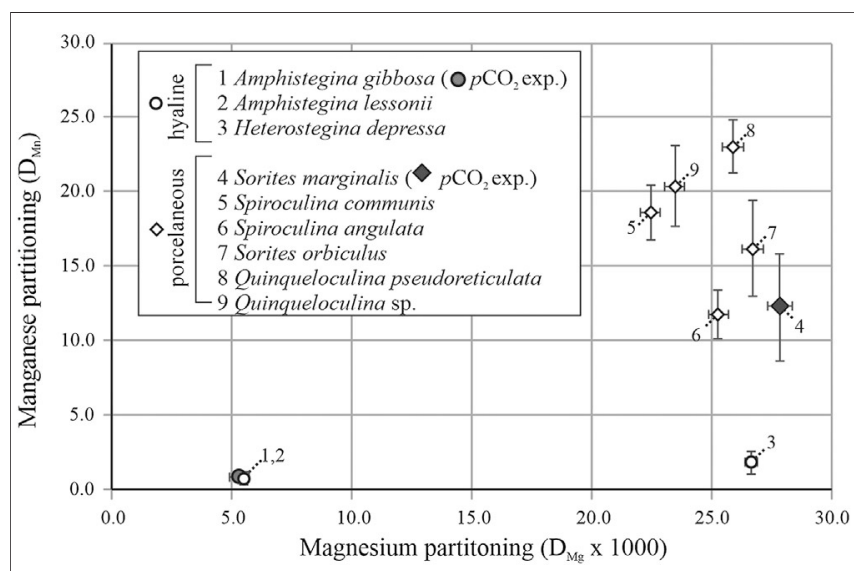

FIGURE 4 | Overview of the average partitioning of $M n\left(D_{M n}\right)$ as a function of $D_{M g} \times 10^{3}$ for foraminiferal species studied here, from both the controlled $\mathrm{pCO}_{2}$ experiment (average value, closed symbols) and the IndoPacific coral reef aquarium (open symbols). Hyaline species and porcelaneous species are indicated with circles and diamond respectively. Error bars indicate SD and numbers indicate species. 
synthetic calcites can be directly translated to biogenic calcite. In our experiments, we measured the average number of newly formed chambers per day for both species and we can conclude that $p \mathrm{CO}_{2}$ concentrations have no impact on their calcification capacity, i.e., chamber addition rates $\left(n\right.$ chambers day $\left.{ }^{-1}\right)$ are stable over the range of culture conditions investigated. However, from these data, we cannot evaluate the calcite precipitation rate itself. As shown by meta-studies on the effect of $\mathrm{pCO}_{2}$ on foraminiferal calcification rates, calculated using a variety of methods by Doo et al. (2014) and Keul et al. (2013), response of foraminifera growth is very species-specific, including negative, positive and no effect growth parameters with increasing $p \mathrm{CO}_{2}$ conditions. Studies that investigate calcification rates of similar species as used in this study in more detail, i.e., by calculating changes in surface area and buoyant weight or shell density as a function of $\mathrm{pH}$, observed opposite trends according to the species considered: no decrease in growth rates for dinoflagellate-bearing porcelaneous species like Marginopora vertebralis after extended periods (30-43 days) at a $\mathrm{pH}$ 7.6-7.4 (Vogel and Uthicke, 2012; Prazeres et al., 2015), while the diatom-bearing A. lessonii showed a steady reduction of shell density and volume at lower $\mathrm{pH}$ (Prazeres et al., 2015). Assuming that the calculated calcification rates in these studies would be correlated to crystal growth rates, there would be no change in precipitation rate in porcelaneous species in the range of $\mathrm{pH}$ studied here and therefore the trend in $\mathrm{Mn} / \mathrm{Ca}$ would not be explained by precipitation rate. However, the link between calcite addition rate and crystal growth rate still needs to be explored. A detailed study on foraminiferal calcification rate, in which chamber addition rates should be clearly decoupled from crystal growth rates, is necessary to evaluate the impact of precipitation rate on foraminiferal $\mathrm{Mn}$ / $\mathrm{Ca}$ values and other elemental ratios in general. Since we cannot prove that the observed trends in $\mathrm{Mn} / \mathrm{Ca}$ are (only) driven by carbonate chemistry-drive changes in crystal growth rates, we also explore other possibilities.

Foraminiferal $\mathrm{Mn} / \mathrm{Ca}$ values may be link to $\mathrm{Ca}-\mathrm{ATPase}$, which appears to play an important role in regulating $\mathrm{Ca}^{2+}$ uptake for calcification (Toyofuku et al., 2017). According to Prazeres et al. (2015), upregulation of Ca-ATPase is confirmed at lower $\mathrm{pH}$ values for A. lessonii. Their interpretation is that the enzyme is used for removing $\mathrm{Ca}^{2+}$ out of the SOC due to shell dissolution. However, this is not logical due to the large amount of $\mathrm{Ca}^{2+}$ foraminifera need for calcification (De Nooijer et al., 2009a); even if shell dissolution would lead to an increase in $\mathrm{Ca}^{2+}$ in the SOC (and not the surrounding seawater), this resource is much too valuable to transport outwards. We therefore argue that Ca-ATPase is used in foraminiferal calcification to take up $\mathrm{Ca}^{2+}$, as proposed by Toyofuku et al. (2017). Higher activity of this enzyme might also increase the accidental uptake of $\mathrm{Mn}^{2+}$, due to the similarity in ionic radii of $\mathrm{Mn}^{2+}$ and $\mathrm{Ca}^{2+}$. This would in theory lead to higher $\mathrm{Mn}$ availability in the SOC and therefore incorporation in the shell at lower $\mathrm{pH}$ and higher $p \mathrm{CO}_{2}$. However, this increase in Ca-ATPase activity is not observed for porcelaneous species like $S$. marginalis, in which we also observe a positive correlation between $p \mathrm{CO}_{2}$ and $\mathrm{Mn} / \mathrm{Ca}$ values and can thus not explain the increase in $\mathrm{Mn} / \mathrm{Ca}$ in this species.

\section{Effect of $\mathrm{pCO}_{2}$ on Speciation and Adsorption of $\mathrm{Mn}$}

Incorporation of $\mathrm{Mn}$ might be governed by the speciation of $\mathrm{Mn}$ in seawater with $\mathrm{pCO}_{2}$. Besides $\mathrm{Mn}$, the incorporation of $\mathrm{Ba}$ and $\mathrm{Zn}$ also increases with higher $p \mathrm{CO}_{2}$, which could be explained by changes in the chemical speciation of these elements, induced by seawater carbonate chemistry (Van Dijk et al., 2017b; Van Dijk et al., 2017c). We have tested this hypothesis for Mn using the software package PHREEQC (v.2; Parkhurst and Appelo, 1999) and the standard PHREEQC llnl database, which allows modeling of bioavailability of different chemical species (eg, $\mathrm{Mn}^{2+}, \mathrm{MnCO}_{3}$ ) in seawater. The model shows a shift in element speciation with $p \mathrm{CO}_{2}$ (Figure 5A). When seawater chemistry changes from low $p \mathrm{CO}_{2}$ (or high $\mathrm{pH}$ ) to higher $p \mathrm{CO}_{2}$ (or low $\mathrm{pH}$ ), we observe an increase in the activity of free $\mathrm{Mn}^{2+}$, soluble carbonate-complexes decreases, which is similar to the findings for $\mathrm{Zn}$ and $\mathrm{Ba}$ speciation with $p \mathrm{CO}_{2}$ (Van Dijk et al., 2017b).

When considering other $\mathrm{pH} / \mathrm{CO}_{3}{ }^{2-}$ depending proxies, the increase in $\mathrm{Mn}$ over the studied range in $\mathrm{CCO}_{2}$ is considerably smaller than for example the increase in $\mathrm{Zn}$ incorporation (Van Dijk et al., 2017b). For instance, when comparing the relative change in the activities of $\mathrm{Mn}$ and $\mathrm{Zn}$ (Figure 5B), the change in activity of free $\mathrm{Zn}\left(\mathrm{Zn}^{2+} ; 10 \%\right)$ is larger than the changes in free $\mathrm{Mn}\left(\mathrm{Mn}^{2+} ; 2 \%\right)$. This could then explain why $\mathrm{Zn} / \mathrm{Ca}$ CALCITE is more sensitive to $p \mathrm{CO}_{2}$ compared to $\mathrm{Mn} / \mathrm{Ca}$ CALCITE. For instance, for A. gibbosa, $\mathrm{Mn} / \mathrm{Ca}$ increases $22 \%$ per $100 \mathrm{ppm} \mathrm{CO}_{2}$ (this study; Figure 1), while $\mathrm{Zn} / \mathrm{Ca}$ increases 53\% (Van Dijk et al., $2017 b$ ), which might be due to the higher increase in availability of free ions of $\mathrm{Zn}$ compared to Mn (Figure 5B).

Based on the PHREEQC model, increase in Mn incorporation at higher $p \mathrm{CO}_{2}$ could be explained by more (bio)available $\mathrm{Mn}^{2+}$ (Figures 5C,D) which may be transported by Ca-channels during calcification (Nehrke et al., 2013). However, to accurately model chemical speciation during chamber formation and assess its role in element incorporation, it is crucial to know the carbonate chemistry of both the foraminiferal microenvironment and at the SOC. In addition to the $\mathrm{pH}$ during calcification (De Nooijer et al., 2009; Toyofuku et al., 2017; Glas et al., 2012a) a second parameter of the inorganic carbon system is necessary to reconstruct the complete carbon system inside and outside the foraminifer. Since there are examples of functioning proxies for seawater carbonate chemistry, one of the most established one being the boron isotopic composition of foraminiferal shells as a proxy for seawater pH (e.g., Sanyal et al., 1996; Pagani et al., 2005; Foster and Rae, 2016), it is likely that the external and internal $\mathrm{pH}$ are in some way affected by ocean acidification.

Finally, Barras et al. (2018) suggested that Mn might be (partially) incorporated into the shell by incorporation into adsorption layers. This was hypothesized to explain different ontogenetic trends (differences in chamber to chamber values of $\mathrm{Mn} / \mathrm{Ca}$ ) observed between species of (deep-sea and intertidal) small benthic foraminifera. Sorption of divalent metals, like $\mathrm{Mn}^{2+}$, on the surface of synthetic calcite is $\mathrm{pH}$ dependent (Zachara et al., 1991), with lower $\mathrm{pH}$ resulting in lower adsorption. If such adsorption process would exist in large tropical species, which has not been proven yet, we would have expected that higher $p \mathrm{CO}_{2}$ would decrease $\mathrm{Mn}$ 

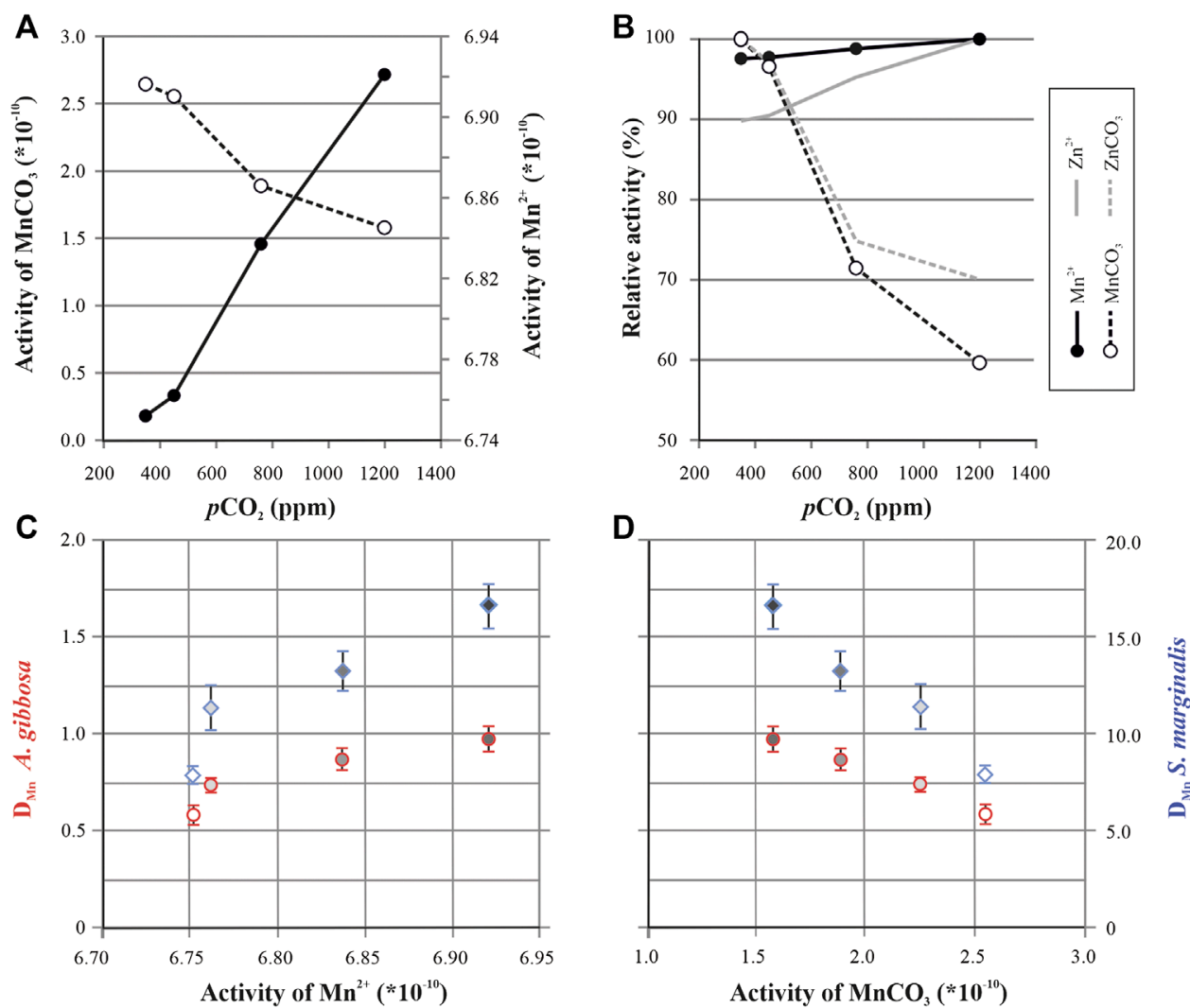

FIGURE 5 | Modeled activity of Mn by PHREEQC. Speciation of free ( $\mathrm{Mn}^{2+}$; closed symbols) and complexed (MnCO ${ }_{3}$; open symbols) $\mathrm{Mn}$ plotted as a function of $\mathrm{pCO}_{2}$ (A). Relative change in activity of free $\mathrm{Mn}^{2+}$ and $\mathrm{Mn}^{-\mathrm{CO}_{3}}$ complexes (B) plotted together with relative activity changes of free $\mathrm{Zn}{ }^{2+}$ (solid gray line) and $\mathrm{ZnCO}{ }_{3}$ complexes (dashed gray line) from van Dijk et al. (2017c). Mn partitioning for both species (A. gibbosa = red circles; Sorites marginalis = blue diamonds) as a function of $\mathrm{Mn}^{2+}$ activity (C) and $\mathrm{MnCO}_{3}$ activity (D), with symbol filling corresponding to $\mathrm{pCO}_{2}$ of the treatments, in which darker filling represents higher $p C \mathrm{C}_{2}$ conditions, see also Figure 2.

incorporation. However, we observe the exact opposite. Either the hypothesis of adsorption layers playing a role during biocalcification is not correct, at least for both large benthic species studied here, or this effect is much smaller and therefore negligible compared to e.g., changes in $\mathrm{Mn}$ speciation.

\section{Manganese Incorporation in Different Species of Foraminifera}

Since speciation of $\mathrm{Mn}$ is sensitive to carbonate chemistry of the seawater (Figure 5A) and also at the SOC, offsets in internal $\mathrm{pH}$ during calcification between species might be responsible for observed difference in $\mathrm{Mn}$ incorporation. Since internal (De Nooijer et al., 2009a) and external pH (Glas et al., 2012b) are linked due to proton pumping (Toyofuku et al., 2017), a higher internal $\mathrm{pH}$ would correspond to a lower $\mathrm{pH}$ in the foraminiferal microenvironment. This will lead in turn to a higher activity of free Mn outside the organism, which could be transported through Cachannels. Following this hypothesis, foraminifera with higher $\mathrm{Mn} /$ $\mathrm{Ca}$, like $H$. depressa (Figure 4), might have a higher passive transport of $\mathrm{Mn}$ and/or a higher internal $\mathrm{pH}$ during calcification compared to A. gibbosa. No independent evidence exists, however, for such a difference in internal $\mathrm{pH}$ between species or between the groups precipitating a hyaline or porcelaneous shell. For example, for hyaline species, also changes in the regulation of Ca-ATPase (Prazeres et al., 2015) between species might be responsible for the observed differences in Mn incorporation.

When investigating $\mathrm{Mn}$ incorporation across a wider range of foraminiferal species, we observe that overall $\mathrm{Mn} / \mathrm{Ca}$ values seem linked to $\mathrm{Mg}$ content which seems to primarily reflect calcification strategy (Figure 4). Porcelaneous species incorporate in general more $\mathrm{Mn}$ and $\mathrm{Mg}$, however we observe no correlation between shell $\mathrm{Mg} / \mathrm{Ca}$ and $\mathrm{Mn} / \mathrm{Ca}$ within this group of species. In contrast, within the hyaline species, we observe that species that have a higher $\mathrm{Mg}$ content also incorporate more $\mathrm{Mn}$. Based on inorganic precipitation experiments, higher precipitation rates would lead to higher $\mathrm{Mg}$ partitioning (Mavromatis et al., 2013), but would also lower Mn/ $\mathrm{Ca}_{\text {CALCITE }}$ due to a decrease in partitioning (Lorens, 1981). This could potentially explain the observed increase of $\mathrm{Mg} / \mathrm{Ca}$ CALCiTE and simultaneous decrease of $\mathrm{Mn} / \mathrm{Ca}_{\mathrm{CALCITE}}$ with temperature in cultured A. lessonii (Van Dijk et al., 2019a). However, it does not explain the trends we observe for different hyaline and porcelaneous species (Figure 4), in which both $\mathrm{Mg} / \mathrm{Ca}$ and $\mathrm{Mn} / \mathrm{Ca}$ increase in concert. Whatever the cause of the offset in $\mathrm{Mg}$ content between species (discussed in more detail in Van Dijk et al., 2019a), difference in $\mathrm{Mg} / \mathrm{Ca}$ can potentially by itself alter the 
incorporation of other elements, through crystal lattice distortion. Based on inorganic experiments, $\mathrm{Mg}$ incorporation alters the structure of the crystal lattice (Mucci, 1987) and the resulting strain on the destabilized crystal lattice allows for higher incorporation of other trace metals. Lattice distortion has been proposed before to explain an increase in $\mathrm{Na}$ with $\mathrm{Mg}$ for larger benthic foraminifera (e.g., Evans et al., 2015). Similarly, this might explain the observed trends for hyaline species, for which we observe a co-variation of $\mathrm{Mn} / \mathrm{Ca}$ and $\mathrm{Mg} / \mathrm{Ca}$ between individuals (Figure 2) and between species (Figure 4). However, this would also imply that porcelaneous, and high-Mg hyaline species that have the same $\mathrm{D}_{\mathrm{Mg}}$ as high-Mg porcelaneous species (like H. depressa), should have a similar $\mathrm{D}_{\mathrm{Mn}}$. However, hyaline species have lower calcite $\mathrm{Mn} / \mathrm{Ca}$ values compared to porcelaneous species, even when looking at species with similar $\mathrm{Mg}$ content, for instance $H$. depressa $\left(\mathrm{D}_{\mathrm{Mg}} \times 10^{3}=26.7, \mathrm{D}_{\mathrm{Mn}}=1.9\right)$ compared to $S$. marginalis $\left(\mathrm{D}_{\mathrm{Mg}} \times\right.$ $10^{3}=26.6, \mathrm{D}_{\mathrm{Mn}}=13.2$ ), which incorporates $\sim 7$ times more $\mathrm{Mn}$ while $\mathrm{Mg}$ content is similar (Figure 4). This suggests there is an additional process, probably fundamentally related to calcification of either hyaline or porcelaneous shells, which respectively decreases or increases the $\mathrm{Mn} / \mathrm{Ca}$ of the precipitated calcite.

\section{Potential Constrains for Mn/Ca As a (Paleo-) Oxygenation Proxy}

In this study we observed that partitioning of $\mathrm{Mn}$ is speciesspecific and that $\mathrm{Mn} / \mathrm{Ca}$ is positively correlated with $\mathrm{pCO}_{2}$ (Figure 1) and/or negatively correlated with $\mathrm{pH},\left[\mathrm{CO}_{3}{ }^{2-}\right], \Omega$ (Supplementary Figure S1). Although it is complicated to incisively explain this empirical relation with a single process, these observations have to be taken into account when applying $\mathrm{Mn} / \mathrm{Ca}$ to field or (sub) geological samples as a proxy for oxygenation (Groeneveld and Filipsson, 2013; Ní Fhlaithearta et al., 2018; Petersen et al., 2018; Guo et al., 2019). Calibrations of the $\mathrm{Mn} / \mathrm{Ca}$ oxygenation proxy for foraminifera require quantifying the direct impact of carbonate parameters on the proxy sensitivity, especially since covariation between $p \mathrm{CO}_{2}$ and oxygenation can occur in benthic environments. However, we expect that for benthic species the impact of differences in carbonate chemistry on foraminiferal $\mathrm{Mn} / \mathrm{Ca}$ is limited compared to the effect of oxygen-induced changes in $\mathrm{Mn}^{2+}$ and subsequently foraminiferal $\mathrm{Mn} / \mathrm{Ca}$, due to the low sensitivity observed in this study (Figure 1). Further studies are needed to decouple the effect of both environmental parameters, like obtaining sensitivity of $\mathrm{Mn} / \mathrm{Ca}$ of larger benthic species to changes in $\mathrm{O}_{2} /$ seawater $\left[\mathrm{Mn}^{2+}\right]$. Furthermore, for calibration studies, in the water column, parameters of the carbonate chemistry will behave similar to this culture experiments, but in the sediment, characterized by high alkalinity, changes in carbonate chemistry might be buffered, and fluctuations in e.g., $\mathrm{pH}$ could therefore become negligible. More importantly, our observations of major differences in $\mathrm{Mn}$ incorporation between hyaline, both low and high Mg species, and porcelaneous species (Figure 4) is crucial to take into account for calibration and application of a potential $\mathrm{O}_{2}$ proxy. Reconstructing oxygen concentration requires species-specific calibrations for $\mathrm{Mn} / \mathrm{Ca}$ as well as insight into factors potentially affecting $\mathrm{Mn}$ speciation.

\section{CONCLUSIONS}

Manganese incorporation in two larger benthic foraminifera, A. gibbosa and S. marginalis is shown to be affected by seawater carbonate chemistry. Average chamber addition rate in the studied species is not impacted by the range in carbonate chemistry studies in this short-term culture experiment. We show that for both species, grown in controlled conditions, shell $\mathrm{Mn} / \mathrm{Ca}$ increases with $p \mathrm{CO}_{2}$ and hypothesize that this might not (only) be caused by changes of growth or precipitation rate or adsorption of $\mathrm{Mn}$ to the shell surface, but is likely impacted by changes in Mn speciation in seawater. Furthermore, in contrast to porcelaneous species, $\mathrm{Mg}$ and $\mathrm{Mn}$ incorporation in hyaline species seems to be correlated on specimen and species level, suggesting that the transport of both ions is somehow coupled during foraminiferal calcification. The high species-specific differences in partitioning of $\mathrm{Mn}$ calls for species-specific calibrations for $\mathrm{Mn} / \mathrm{Ca}$ with oxygen content for proper application of the foraminiferal based Mn-oxygen proxy.

\section{DATA AVAILABILITY STATEMENT}

The raw data supporting the conclusions of this article will be made available by the authors, without undue reservation. LAICP-MS data is provided in the Supplementary Material.

\section{AUTHOR CONTRIBUTIONS}

IvD, LdN, and GJR designed the experiment, IvD performed the experiment and measurements. IvD, LdN, CB, and GJR discussed the data and wrote the manuscript. All authors contributed to data interpretation and writing of the final manuscript.

\section{FUNDING}

Main funding comes from Darwin Center for Biogeosciences (project 3020) and Netherlands Earth System Science Center (NESSC; Grant No. 024.002.001) to GJR with additional funding from University Bretagne Loire and Angers Loire Metropole (France) to CB. Experimental set-up was financed by NWO Grants 858.14.021 and 858.14.022.

\section{ACKNOWLEDGMENTS}

We would like to thank Johan Stapel for hosting the 2015 foraminiferal culture expedition at the CNSI, St. Eustatius, as well as all the participants, especially Esmee Geerken and Alice Webb. The controlled $p \mathrm{CO}_{2}$ set-up used in this study was designed and constructed by Steven van Heuven and Bob Koster (NWO Grants 858.14.021 and 858.14.022). We acknowledge Max Janse and Burgers' Zoo for the samples 
from the tropical aquarium. Great thanks to Wim Boer for support with LA-Q-ICP-MS measurements and we would like to thank Kirsten Kooijman (Algae culturing), Patrick Laan (SFICP-MS), Karel Bakker (DIC) and Jan-Berend Stuut (SEM) for analysis and lab support.

\section{REFERENCES}

Barker, S., Cacho, I., Benway, H., and Tachikawa, K. (2005). Planktonic foraminiferal $\mathrm{Mg} / \mathrm{Ca}$ as a proxy for past oceanic temperatures: a methodological overview and data compilation for the Last Glacial Maximum. Quat. Sci. Rev. 24, 821-834. doi:10.1016/j.quascirev.2004.07.016

Barker, S., Greaves, M., and Elderfield, H. (2003). A study of cleaning procedures used for foraminiferal Mg/Ca paleothermometry. Geochem. Geophys. Geosyst. 4, 1-8. doi:10.1029/2003gc000559

Barras, C., Mouret, A., Nardelli, M. P., Metzger, E., Petersen, J., La, C., et al. (2018). Experimental calibration of manganese incorporation in foraminiferal calcite. Geochim. Cosmochim. Acta. 237, 49-64. doi:10.1016/ j.gca.2018.06.009

Bé, A. W. H., Hemleben, C., Anderson, O. R., Spindler, M., and Be, A. W. H. (1979). Chamber formation in planktonic foraminifera. Micropaleontology. 25, 294-307. doi:10.2307/1485304

Bentov, S., Brownlee, C., and Erez, J. (2009). The role of seawater endocytosis in the biomineralization process in calcareous foraminifera. Proc. Natl. Acad. Sci. U. S. A. 106, 21500-21504. doi:10.1073/pnas.0906636106

Bentov, S., and Erez, J. (2006). Impact of biomineralization processes on the $\mathrm{Mg}$ content of foraminiferal shells: a biological perspective. Geochem. Geophys. Geosyst. 7, 319. doi:10.1029/2005gc001015

de Nooijer, L. J., Spero, H. J., Erez, J., Bijma, J., and Reichart, G. J. (2014). Biomineralization in perforate foraminifera. Earth Sci. Rev. 135, 48-58. doi:10.1016/j.earscirev.2014.03.013

de Nooijer, L. J., Toyofuku, T., and Kitazato, H. (2009a). Foraminifera promote calcification by elevating their intracellular $\mathrm{pH}$. Proc. Natl. Acad. Sci. U.S.A. 106, 15374-15378. doi:10.1073/pnas.0904306106

de Nooijer, L. J., Langer, G., Nehrke, G., and Bijma, J. (2009b). Physiological controls on seawater uptake and calcification in the benthic foraminifer Ammonia tepida. Biogeosciences. 6, 2669-2675.

Doo, S. S., Fujita, K., Byrne, M., and Uthicke, S. (2014). Fate of calcifying tropical symbiont-bearing large benthic foraminifera: living sands in a changing ocean. Biol. Bull. 226, 169-186. doi:10.1086/bblv226n3p169

Elderfield, H., Bertram, C., and Erez, J. (1996). A biomineralization model for the incorporation of trace elements into foraminiferal calcium carbonate. Earth Planet. Sci. Lett. 142, 409-423. doi:10.1016/0012-821x(96)00105-7

Erez, J. (2003). The source of ions for biomineralization in foraminifera and their implications for paleoceanographic proxies. Rev. Mineral. Geochem. 54, 115-150. doi:10.2113/0540115

Ernst, S., Janse, M., Renema, W., Kouwenhoven, T., Goudeau, M.-L., and Reichart, G.-J. (2011). Benthic foraminifera in a large Indo-Pacific coral reef aquarium. J. Foraminifer. Res. 41, 101-113. doi:10.2113/gsjfr.41.2.101

Evans, D., Erez, J., Oron, S., and Müller, W. (2015). Mg/Ca-temperature and seawater-test chemistry relationships in the shallow-dwelling large benthic foraminifera Operculina ammonoides. Geochim. Cosmochim. Acta. 148, 325-342. doi:10.1016/j.gca.2014.09.039

Evans, D., Müller, W., and Erez, J. (2018). Assessing foraminifera biomineralisation models through trace element data of cultures under variable seawater chemistry. Geochim. Cosmochim. Acta. 236, 198-217. doi:10.1016/j.gca.2018.02.048

Foster, G. L., and Rae, J. W. B. (2016). Reconstructing ocean pH with boron isotopes in foraminifera. Ann. Rev. Earth Planet. Sci. 44, 207-237. doi:10.1146/ annurev-earth-060115-012226

Glas, M. S., Fabricius, K. E., de Beer, D., and Uthicke, S. (2012a). The $\mathrm{O}^{2}$, pH and $\mathrm{Ca}^{2+}$ microenvironment of benthic foraminifera in a high $\mathrm{CO}_{2}$ world. PLoS ONE. 7, e50010. doi:10.1371/journal.pone.0050010

Glas, M. S., Langer, G., and Keul, N. (2012b). Calcification acidifies the microenvironment of a benthic foraminifer (Ammonia sp.). J. Exp. Mar. Biol. Ecol. 424-425, 53-58. doi:10.1016/j.jembe.2012.05.006

\section{SUPPLEMENTARY MATERIAL}

The Supplementary Material for this article can be found online at: $\quad$ https://www.frontiersin.org/articles/10.3389/feart.2020. 567701/full\#supplementary-material

Groeneveld, J., and Filipsson, H. L. (2013). Mg/Ca and $\mathrm{Mn} / \mathrm{Ca}$ ratios in benthic foraminifera: the potential to reconstruct past variations in temperature and hypoxia in shelf regions. Biogeosciences. 10, 5125-5138. doi:10.5194/bg-105125-2013

Gonçalves, P., Meireles, S., Neves, P., and Vale, M. (1999). Ionic selectivity of the $\mathrm{Ca} 2+/ \mathrm{H}+$ antiport in synaptic vesicles of sheep brain cortex. Mol. Brain Res. 67 (2), 283-291. doi:10.1016/S0169-328X(99)00081-9

Guillong, M., Meier, D. L., Allan, M. M., Heinrich, C. A., and Yardley, B. W. (2008). SILLS: a MATLAB-based program for the reduction of laser ablation ICP-MS data of homogeneous materials and inclusions. Miner. Assoc. Canada Short Course Ser. 40, 328-333.

Guo, X., Xu, B., Burnett, W. C., Yu, Z., Yang, S., Huang, X., et al. (2019). A potential proxy for seasonal hypoxia: LA-ICP-MS Mn/Ca ratios in benthic foraminifera from the Yangtze River Estuary. Geochim. Cosmochim. Acta. 245, 290-303. doi:10.1016/j.gca.2018.11.007

Hemleben, C. H., Anderson, O. R., Berthold, W., and Spindler, M. (1986). "Calcification and chamber formation in Foraminifera-a brief overview," in Biomineralization in lower plants and animals. Editors B. S. Leadbeater and R. Riding (Oxford, UK: Clarendon Press), 237-249.

Jacob, D. E., Wirth, R., Agbaje, O. B. A., Branson, O., and Eggins, S. M. (2017). Planktic foraminifera form their shells via metastable carbonate phases. Nat. Commun. 8, 1265. doi:10.1038/s41467-017-00955-0

Keul, N., Langer, G., de Nooijer, L. J., and Bijma, J. (2013). Effect of ocean acidification on the benthic foraminifera. Biogeosciences 10, 6185-6198. doi:10. 5194/bg-10-6185-2013

Keul, N., Langer, G., Thoms, S., de Nooijer, L. J., Reichart, G. J., and Bijma, J. (2017). Exploring foraminiferal $\mathrm{Sr} / \mathrm{Ca}$ as a new carbonate system proxy. Geochem. Cosmochim. Acta. 202, 374-386. doi:10.1016/j.gca.2016.11.022

Koho, K. A., de Nooijer, L. J., and Reichart, G. J. (2015). Combining benthic foraminiferal ecology and shell $\mathrm{Mn} / \mathrm{Ca}$ to deconvolve past bottom water oxygenation and paleoproductivity. Geochem. Cosmochim. Acta. 165, 294-306. doi:10.1016/j.gca.2015.06.003

Kroeker, K. J., Kordas, R. L., Crim, R., Hendriks, I. E., Ramajo, L., Singh, G. S., et al. (2013). Impacts of ocean acidification on marine organisms: quantifying sensitivities and interaction with warming. Glob. Chang. Biol. 19, 1884-1896. doi:10.1111/gcb.12179

Lear, C. H., Elderfield, H., and Wilson, P. A. (2000). Cenozoic deep-Sea temperatures and global ice volumes from $\mathrm{Mg} / \mathrm{Ca}$ in benthic foraminiferal calcite. Science 287, 269-272. doi:10.1126/science.287.5451.269

Lee, J. J., Morales, J., Symons, A., and Hallock, P. (1995). Diatom symbionts in larger foraminifera from Caribbean hosts. Mar. Micropaleontol. 26, 99-105. doi:10.1016/0377-8398(95)00004-6

Lorens, R. B. (1981). Sr, Cd, Mn and Co distribution coefficients in calcite as a function of calcite precipitation rate. Geochem. Cosmochim. Acta. 45, 553-561. doi:10.1016/0016-7037(81)90188-5

Müller-Merz, E., and Lee, J. J. (1976). Symbiosis in the larger foraminiferan Sorites marginalis (with notes on Archaias spp.). J. Protozool. 23, 390-396. doi:10.1111/ j.1550-7408.1976.tb03793.x

Mavromatis, V., Gautier, Q., Bosc, O., and Schott, J. (2013). Kinetics of Mg partition and $\mathrm{Mg}$ stable isotope fractionation during its incorporation in calcite. Geochem. Cosmochim. Acta. 114, 188-203. doi:10.1016/j.gca.2013.03. 024

McKay, C. L., Groeneveld, J., Filipsson, H. L., Gallego-Torres, D., Whitehouse, M. J., Toyofuku, T., et al. (2015). A comparison of benthic foraminiferal $\mathrm{Mn} / \mathrm{Ca}$ and sedimentary $\mathrm{Mn} / \mathrm{Al}$ as proxies of relative bottom-water oxygenation in the low-latitude NE Atlantic upwelling system. Biogeosciences 12, 5415-5428. doi:10.5194/bg-12-5415-2015

Mewes, A., Langer, G., Reichart, G. J., de Nooijer, L. J., Nehrke, G., and Bijma, J. (2015). The impact of $\mathrm{Mg}$ contents on $\mathrm{Sr}$ partitioning in benthic foraminifers. Chem. Geol. 412, 92-98. doi:10.1016/j.chemgeo.2015.06.026 
Mezger, E. M., de Nooijer, L. J., Boer, W., Brummer, G. J. A., and Reichart, G. J. (2016). Salinity controls on $\mathrm{Na}$ incorporation in Red Sea planktonic foraminifera. Paleoceanography 31, 1562-1582. doi:10.1002/2016pa003052

Middelburg, J. J., De Lange, G. J., and van Der Weijden, C. H. (1987). Manganese solubility control in marine pore waters. Geochem. Cosmochim. Acta. 51, 759-763. doi:10.1016/0016-7037(87)90086-x

Mucci, A. (1987). Influence of temperature on the composition of magnesian calcite overgrowths precipitated from seawater. Geochem. Cosmochim. Acta. 51, 1977-1984. doi:10.1016/0016-7037(87)90186-4

Mucci, A., and Morse, J. W. (1983). The incorporation of $\mathrm{Mg}^{2+}$ and $\mathrm{Sr}^{2+}$ into calcite overgrowths: influences of growth rate and solution composition. Geochem. Cosmochim. Acta. 47, 217-233. doi:10.1016/0016-7037(83)90135-7

Nehrke, G., Keul, N., Langer, G., de Nooijer, L. J., Bijma, J., and Meibom, A. (2013). A new model for biomineralization and trace - element signatures of Foraminifera tests. Biogeosciences 10, 6759-6767. doi:10.5194/bg-10-6759-2013

Ní Fhlaithearta, S., Fontanier, C., Jorissen, F., Mouret, A., Dueñas-Bohórquez, A., and Anschutz, P. (2018). Manganese incorporation in living (stained) benthic foraminiferal shells: a bathymetric and in-sediment study in the Gulf of Lions (NW Mediterranean). Biogeosciences. 15, 6315-6328. doi:10.5194/bg-15-6315-2018

Nürnberg, D., Bijma, J., and Hemleben, C. (1996). Assessing the reliability of magnesium in foraminiferal calcite as a proxy for water mass temperatures. Geochem. Cosmochim. Acta. 60, 803-814. doi:10.1016/0016-7037(95)00446-7

Okai, T., Suzuki, A., Kawahata, H., Terashima, S., and Imai, N. (2002). Preparation of a new geological survey of Japan geochemical reference material: coral JCp-1. Geostand. Newsl. 26, 95-99. doi:10.1111/j.1751-908x.2002.tb00627.x

Orr, J. C., Fabry, V. J., Aumont, O., Bopp, L., Doney, S. C., Feely, R. A., et al. (2005). Anthropogenic ocean acidification over the twenty-first century and its impact on calcifying organisms. Nature 437, 681-686. doi:10.1038/nature04095

Pagani, M., Lemarchand, D., Spivack, A., and Gaillardet, J. (2005). A critical evaluation of the boron isotope-pH proxy: the accuracy of ancient ocean $\mathrm{pH}$ estimates. Geochem. Cosmochim. Acta. 69, 953-961. doi:10.1016/j.gca.2004.07.029

Parkhurst, D. L., and Appelo, C. (1999). User's guide to PHREEQC (version 2): a computer program for speciation, batch-reaction, one-dimensional transport, and inverse geochemical calculations. Denver, CO: US Geological Survey.

Petersen, J., Barras, C., Bézos, A., La, C., de Nooijer, L. J., Meysman, F. J. R., et al. (2018). $\mathrm{Mn} / \mathrm{Ca}$ intra- and inter-test variability in the benthic foraminifer Ammonia tepida. Biogeosciences 15, 331-348. doi:10.5194/bg-15-331-2018

Prazeres, M., Uthicke, S., and Pandolfi, J. M. (2015). Ocean acidification induces biochemical and morphological changes in the calcification process of large benthic foraminifera. Proc. R. Soc. Lond. B Biol. Sci. 282. doi:10.1098/rspb.2014.2782

Reichart, G.-J., Jorissen, F., Anschutz, P., and Mason, P. R. (2003). Single foraminiferal test chemistry records the marine environment. Geology 31, 355-358. doi:10.1130/0091-7613(2003)031<0355:sftcrt $>2.0 . c 0 ; 2$

Ries, J. B., Cohen, A. L., and McCorkle, D. C. (2009). Marine calcifiers exhibit mixed responses to $\mathrm{CO}_{2}$-induced ocean acidification. Geology 37, 1131-1134. doi:10.1130/g30210a.1

Sanyal, A., Hemming, N. G., Broecker, W. S., Lea, D. W., Spero, H. J., and Hanson, G. N. (1996). Oceanic pH control on the boron isotopic composition of foraminifera: evidence from culture experiments. Paleoceanography 11, 513-517. doi:10.1029/96pa01858
Toyofuku, T., Matsuo, M. Y., de Nooijer, L. J., Nagai, Y., Kawada, S., Fujita, K., et al. (2017). Proton pumping accompanies calcification in foraminifera. Nat. Commun. 8, 14145. doi:10.1038/ncomms14145

Toyofuku, T., Suzuki, M., Suga, H., Sakai, S., Suzuki, A., Ishikawa, T., et al. (2011). $\mathrm{Mg} / \mathrm{Ca}$ and $\delta^{18} \mathrm{O}$ in the brackish shallow-water benthic foraminifer Ammonia 'beccarii.' Mar. Micropaleontol. 78, 113-120. doi:10.1016/j.marmicro.2010.11. 003

Tribovillard, N., Algeo, T. J., Lyons, T., and Riboulleau, A. (2006). Trace metals as paleoredox and paleoproductivity proxies: an update. Chem. Geol. 232, 12-32. doi:10.1016/j.chemgeo.2006.02.012

Van Dijk, I., Barras, C., de Nooijer, L. J., Mouret, A., Geerken, E., Oron, S., et al. (2019a). Coupled calcium and inorganic carbon uptake suggested by magnesium and sulfur incorporation in foraminiferal calcite. Biogeosciences 16, 2115-2130. doi:10.5194/bg-16-2115-2019

Van Dijk, I., de Nooijer, L. J., Boer, W., and Reichart, G. J. (2017a). Sulfur in foraminiferal calcite as a potential proxy for seawater carbonate ion concentration. Earth Planet Sci. Lett. 470, 64-72. doi:10.1016/j.epsl.2017. 04.031

Van Dijk, I., de Nooijer, L. J., and Reichart, G. J. (2017b). Trends in element incorporation in hyaline and porcelaneous foraminifera as a function of $\mathrm{pCO}_{2}$. Biogeosciences 14, 497-510. doi:10.5194/bg-14-497-2017

Van Dijk, I., de Nooijer, L. J., Wolthers, M., and Reichart, G. J. (2017c). Impacts of $\mathrm{pH}$ and $\left[\mathrm{CO}_{3}{ }^{2-}\right]$ on the incorporation of $\mathrm{Zn}$ in foraminiferal calcite. Geochem. Cosmochim. Acta. 197, 263-277. doi:10.1016/j.gca.2016.10.031

Van Dijk, I., Mouret, A., Cotte, M., Le Houedec, S., Oron, S., Reichart, G.-J., et al. (2019b). Chemical heterogeneity of $\mathrm{Mg}, \mathrm{Mn}, \mathrm{Na}, \mathrm{S}$, and $\mathrm{Sr}$ in benthic foraminiferal calcite. Front. Earth Sci. 7, 281. doi:10.3389/feart.2019. 00281

Vogel, N., and Uthicke, S. (2012). Calcification and photobiology in symbiontbearing benthic foraminifera and responses to a high $\mathrm{CO}_{2}$ environment. J. Exp. Mar. Biol. Ecol. 424-425, 15-24. doi:10.1016/j.jembe.2012.05.008

Webb, A. E., van Heuven, S. M. A. C., de Bakker, D. M., van Duyl, F. C., Reichart, G.-J., and de Nooijer, L. J. (2017). Combined effects of experimental acidification and eutrophication on reef sponge bioerosion rates. Front. Mar. Sci.4, 313-315. doi:10.3389/fmars.2017.00311

Zachara, J. M., Cowan, C. E., and Resch, C. T. (1991). Sorption of divalent metals on calcite. Geochem. Cosmochim. Acta. 55, 1549-1562. doi:10.1016/00167037(91)90127-q

Conflict of Interest: The authors declare that the research was conducted in the absence of any commercial or financial relationships that could be construed as a potential conflict of interest.

Copyright (c) 2020 van Dijk, de Nooijer, Barras and Reichart. This is an open-access article distributed under the terms of the Creative Commons Attribution License (CC $B Y)$. The use, distribution or reproduction in other forums is permitted, provided the original author(s) and the copyright owner(s) are credited and that the original publication in this journal is cited, in accordance with accepted academic practice. No use, distribution or reproduction is permitted which does not comply with these terms. 